\title{
ANALISIS AUTHENTIC PERSONAL BRANDING FASHION BLOGGER OLIVIA LAZUARDY (Studi Deskriptif terhadap Akun @olivialazuardy)
}

Oleh :

\author{
EMIKA VALLERIE HUZAFAHMAZIDAH, DINI SALMIYAH FITHRAH ALI
}

\author{
Fakultas Komunikasi dan Bisnis Universitas Telkom
}

\begin{abstract}
Instagram is a social media that often used nowadays. Instagram can be the media for a person to build a Personal Branding in order to reach certain visions. Fashion Blogger can use Instagram to communicate visually through picture uploads on their profile. In order to compete in the market and to be authentic, Fashion Blogger need an Authentic Personal Branding. Olivia Lazuardy is a Fashion Blogger that has been receiving awards in the fashion industry for the past 2 years. The purpose of this study is to learn the application of Authentic Personal Branding Criterias that Olivia Lazuardy applied as a Fashion Blogger. The result of the study is that Olivia is authentic, has consistency, is relevant to her audience interests, has a visibility, can be called as an effective leader, have a good relationship with followers and brands, and has a good performance. Researcher suggests that Olivia should pay more attention to make a differentiation to be the most superior in the market as a Fashion Blogger. Moreover, researcher also suggests that Olivia should build a wider network by managing relationship with local brands.
\end{abstract}

Keywords: personal branding, social media, instagram, fashion blogger, authentic personal branding

\section{PENDAHULUAN}

Branding kini tidak hanya untuk korporasi saja.Ada sebuah tren baru yang dinamakan Personal Branding.Pemicu adanya Personal Branding menurut Jane Tabachnik (2007) dalam buku Sukses Membangun Authentic Personal Branding (2008: 2-3) adalah revolusi teknologi dalam pengembangan karier dan dapat membuat merek pribadi menjadi sarana yang efektif untuk membantu menunjukkan sosok pribadi. Selain itu, perubahan dalam cara berkomunikasi. Internet telah mendorong masing-masing kita untuk atas nama diri pribadi sekalipun.

Perkembangan teknologi dan informasi melahirkan berbagai profesi baru yang bermodalkan media sosial, seperti Fashion Blogger. Fashion Blogger tidak asing lagi ditelinga karena kini di Indonesia sudah banyak Fashion Blogger yang bermunculan. Fashion Blogger mampu menjadikan rujukan dalam bidang mode bagi sekian banyak followersyang dimilikinya. Lebih dari itu, Fashion Blogger yang baik dapat mengelola akunakun media sosial miliknya dengan ribuan followers sehingga menjadi sasaran brand besar untuk melakukan kerjasama bersama dengan mereka. Hal ini yang dinamakan membangun Personal Branding.

Fashion Blogger yang kini memiliki pengikut terbanyak antara lain Olivia Lazuardy, Sonia Eryka, Elxi Elvina dan Michelle Hendra. Pada Agustus 2017 lalu, ESMOD Fashion Design \& Business School mengadakan penghargaan 'Fashion Art Vibes Young Influencer Award'.Pada kategori 'The Most Favorite Fashion Influencer' atau penghargaan 'Fashion Influencer Terfavorit', Olivia Lazuardy berjajaran dengan Elxi Elvina dan Michelle Hendra turut menjadi nominasi.Selain dinobatkan menjadi Fashion Influencer, 
ketiganya juga memiliki Blog dengan konten fashion. Sedangkan Sonia Eryka, adalah Fashion Blogger asal Indonesia yang sudah memulai Blognya lebih dulu diantara ketiga Blogger yakni sejak ia duduk di bangku SMP. Sonia Eryka kini masih aktif dalam media sosial baik dalam Blog pribadinya maupun media sosial Instagram.

Olivia Lazuardy adalah Fashion Blogger asal Indonesia yang turut aktif mengembangkan dirinya pada media sosial Instagram.Ia memulai karir profesionalnya dengan menulis blog khusus fashion pada 2013 silam dengan blog yang beralamatkan www.olivialazuardy.com. Kini, Olivia memiliki lebih dari 250.000 pengikut dalam akun Instagramnya.Selain aktif dalam Blogging dan Instagram, Olivia juga memiliki akun Youtube.

Sebagai Fashion Blogger, Olivia banyak melakukan kerjasama dengan sejumlah brand fashion. Salah satu kerjasama yang baru-baru ini dilakukan Olivia adalah bersama dengan merek fashion mewah internasional, Louis Vuitton, dan brand sports internasional, Reebok. Hal ini tentunya menunjukkan kredibilitas Olivia sebagai Fashion Blogger yang handal karena berhasil menggaet brand internasional untuk bekerjasama dengannya.

Olivia bahkan lebih unggul diantara Fashion Blogger lain yang menjadi pesaingnya karena Olivia turut dinominasikan juga sebagai 'Influencer of the Year' secara general pada Instagram. Olivia bersandingan dengan orang-orang dari bidang yang berbeda.Hal ini turut membuktikan bahwa Olivia memiliki peranan yang kuat sebagai Fashion Blogger sehingga dapat menjadi Influencer pada umumnya di media sosial Instagram.

Penelitian ini memiliki tujuan untuk mengetahui kriteria keotentikan Personal Branding yang dimiliki Olivia Lazuardy sehingga dapat menarik perhatian berbgaai brand untuk menggunakan jasanya sebagai Fashoina Blogger melalui media sosial Instagram. Berdasarkan uraian latar belakang diatas, maka peneliti tertarik untuk menganalisis bagaimana penerapan Autenthic Personal Branding Fashion Blogger Olivia Lazuardy?

\section{METODE PENELITIAN}

Penelitian ini menggunakan metode penelitian deskriptif kualitatif.Menurut Bogdan dan Taylor (1975:5) dalam Moleong (2014), metodologi kualitatif didefinisikan sebagai prosedur penelitian yang menghasilkan data deskriptif berupa kata-kata tertulis atau lisan dari orangorang dan perilaku yang dapat diamati. Penelitian yang menggunakan metode deskriptif adalah penelitian yang dimaksudkan untuk melukiskan, menggambarkan, atau memaparkan keadaan objek yang diteliti sebagaimana apa adanya, sesuai dengan situasi dan kondisi ketika penelitian tersebut dilakukan.

\section{HASIL DAN PEMBAHASAN}

Peneliti akan menguraikan hasil analisis kriteria Authentic Personal Branding Fashion Blogger Olivia Lazuardy melalui akun Instagram @olivialazuardy. Analisa akan dilakukan berdasarkan 11 kriteria Authentic Personal Branding yang Efektif oleh Rampersad (2008).

Personal Branding yang otentik dapat menunjukkan seseorang untuk hidup yang lebih bahagia dan lebih berhasil. Dalam proses untuk membentuk Authentic Personal Branding harus ada keselarasan pikiran dan membuatnya mengerahkan seluruh energi positif, melakukan apa yang disukai, dan senantiasa mengembangkan diri. Merek Pribadi harus dapat mencerminkan karakter asli dan harus dibangun berdasarkan nilai-nilai, kekuatan, keunikan dan keunggulan seseorang.Personal Branding yang berkelanjutan, otentik, konsisten, dan mudah diingat memiliki kriteria-kriteria yang dikemukakan oleh Peter Montoya (2005) dan Rampersad (2006, 2007). 
1. Keotentikan

Rampersad (2008: 39) menyebutkan bahwa Ambisi Pribadi dan Merek Pribadi memungkinkan seseorang untuk merumuskan mimpi, peran utama, tujuan hidup, keunikan, dan nilai-nilai seseorang secara jujur.Melalui kriteria keotentikan oleh Rampersad (2008), peneliti dapat menyimpulkan bahwa Olivia telah memenuhinya karena dapat mencerminkan karakter, visi dan juga nilai yang selaras dengan Ambisi Pribadi dengan menjadi Fashion Blogger melalui Instagram.

2. Integritas

Rampersad (2008: 147) menyebutkan bahwa apabila tindakan, perilaku, dan pemikiran seseorang mencerminkan nilai-nilai yang dimilikinya maka akan menghasilkan integritas pribadi. Dengan demikian, peneliti dapat mengambil kesimpulan bahwa Olivia Lazuardy telah memenuhi kriteria integritas dalam Authentic Personal Branding menurut Rampersad (2008) karena menerapkan perilaku yang sesuai dengan pedoman moral yang telah ditetapkannya yakni sebagai Fashion Blogger.

3. Konsistensi

Melalui kriteria konsistensi menurut Rampersad (2008), peneliti jatuh pada kesimpulan bahwa follower atau target audiens yang dimiliki oleh Olivia dapat mengandalkan gaya berbusana nuansa feminin dengan mengakses akun Instagramnya. Peneliti juga beranggapan bahwa Olivia tetap mengunggah secara relevan ciri khas pada dirinya tanpa menjadi kaku karena karena tekad untuk berkembang yang dimiliki oleh Olivia.

4. Spesialisasi

Menurut Rampersad (2008: 81), setelah menentukan spesialisasi atau bidang keahlian maka seseorang harus fokus dan berkonsentrasi pada keterampilan tersebut. Dalam konsep Personal Branding otentik, maka spesialisasi harus dibangun melalui impian, nilainilai, peranan utama, dan tujuan hidup. Peneliti dapat menyimpulkan bahwa Olivia dapat memenuhi kriteria spesialisasi menurut Rampersad (2008) karena dapat menetapkan bidang spesialisasi yakni fashion dan berupaya dalam menyampaikan pesannya secara unik.

5. Otoritas

Rampersad (2008) menyatakan bahwa kriteria otoritas adalah seseorang yang dapat dikatakan sebagai pemimpin yang efektif.Melalui pemarapan di atas, peneliti dapat menyimpulkan bahwa Olivia dengan sangat baik memenuhi kriteria otoritas oleh Rampersad (2008).

6. Keberbedaan

Dalam membangun keberbedaan atau diferensiasi, Rampersad (2008) berpendapat bahwa Personal Branding harus berbeda dan memiliki nilai tambah bagi orang lain. Walaupun ada upaya untuk menjadi berbeda, peneliti menarik kesimpulan bahwa Olivia tidak dapat memenuhi kriteria keberbedaan dalam Authentic Personal Branding yang efektif menurut Rampersad (2008).

7. Relevan

Relevan dalam Authentic Personal Branding dinyatakan Rampersad (2008) sebagai kemampuan dalam menyampaikan pesan yang dianggap penting oleh audiens sasaran.Dengan demikian, peneliti memiliki kesimpulan bahwa Olivia memenuhi kriteria relevan pada Authentic Personal Branding (Rampersad, 2008). Peneliti dapat memiliki kesimpulan demikian karena Olivia memiliki upaya dalam penyampaian pesan untuk memenuhi kebutuhan target audiens.

8. Visibilitas

Visibilitas dalam Authentic Personal Branding diartikan Rampersad (2008) sebagai penyampaian pesan yang berkali-kali dan terus menerus.Peneliti melihat upaya Olivia dalam melakukan konsistensi dalam jangka waktu 
panjang sebagai Fashion Blogger.Dengan demikian, dapat disimpulkan bahwa visibilitas menurut Rampersad (2008) yang dilakukan oleh Olivia dapat dikatakan baik.Hal ini terbukti dengan konsistensi pemaparan pesan Personal Branding yang kerap dilakukan Olivia hingga sampai pada pemahaman follower.

9. Persistensi

Persistensi dalam Personal Branding adalah mengembangkan Personal Branding yang konsisten selama periode panjang dengan dedikasi yang tinggi dalam melakukannya (Rampersad, 2008).Dengan demikian, peneliti menyimpulkan bahwa Olivia memiliki persistensi yang baik dalam Personal Branding.Hal ini dikarenakan Olivia melakukan sejumlah perencanaan untuk menghasilkan tampilan Instagram yang menggambarkan dirinya secara maksimal. Adapun keraguan yang dimiliki dirinya terhadap masa depan sebagai Fashion Blogger, Olivia tetap berusaha menggabungkan konten fashion dan personalnya untuk lebih dekat lagi dengan followers. Maka dari itu, peneliti menyimpulkan bahwa Olivia memenuhi kriteria persistensi oleh Rampersad (2008) dengan baik.

10. Goodwill

Dari uraian diatas, peneliti menyimpulkan bahwa Olivia belum dapat memenuhi kriteria goodwill berdasarkan Rampersad (2008) dengan baik. Olivia terbukti telah berupaya membangun goodwill dengan followers maupun brand luxury. Namun, Peneliti melihat bahwa adanya kekurangan Olivia dalam membangun goodwill dengan brand-brand lokal.

11. Kinerja

Olivia telah memenuhi kriteria kinerja menurut Rampersad (2008) dengan sangat baik.Olivia memiliki usaha dalam menjaga Personal Branding sangat baik.Lebih dari itu, Olivia memiliki tolak ukuran secara kuantitatif untuk dapat memenuhi target pribadi yang telah dirumuskannya yakni menjadi Fashion Blogger yang terkenal secara mendunia.

\section{PENUTUP}

Olivia Lazuardy sebagai Fashion Blogger melalui akun Instagram @olivialazuardy telah menerapkan sembilan dari kriteria Authentic Personal Branding yang efektif (Rampersad, 2008).Ulasan pertama berkaitan dengan keotentikan.Olivia telah dengan baik menampilkan karakter, nilai dan visi yang selaras dengan ambisi pribadinya yakni pada dunia fashion.Instagram merupakan wadah yang menampilkan pesan secara visual, Olivia sebagai Fashion Blogger memiliki peran dalam pencapaian visinya yang menjalani profesi tersebut.Kedua, kriteria integritas.Olivia telah berupaya dalam menerapkan integritas pada Personal Branding dengan baik.Ulasan ketiga adalah konsistensi.Dalam menjaga konsistensinya, Olivia dapat dikatakan melakukan konsistensi tanpa menjadikan dirinya seseorang yang pasif.Peneliti juga dapat menyimpulkan bahwa Olivia memenuhi kriteria keempat yakni spesialisasi.

Hal ini dikarenakan Olivia tekun dalam menjaga fashion sebagai fokus utama dalam melakukan Personal Branding. Terkait dengan ulasan kriteria otoritas, Olivia disimpulkan telah dengan baik memenuhi kredibilitas sebagai pemimpin dalam fashion. Olivia terbukti mendapatkan nominasi bahkan menerima penghargaan yang berhubungan dengan fashion sehingga membuatnya dianggap sebagai pemimpin.Selanjutnya, Olivia juga senantiasa untuk menyampaikan pesan yang berarti bagi target audiensnya melalui posting Instagram tentang fashion.Hal ini membuat Olivia memenuhi kriteria relevan.Dalam hal visibilitas, Olivia kerap melakukan pemaparan pesan Personal Branding yang konsisten.Sejak awal pembuatan hingga saat ini, Olivia selalu melakukan posting yang berkaitan dengan fashion. 
Maka dapat disimpulkan Olivia memenuhi kriteria visibilitas dengan baik.Ulasan berikutnya adalah kriteria persistensi.Olivia telah memenuhi kriteria persistensi yang baik dalam Personal Branding.Hal ini dikarenakan Olivia melakukan sejumlah perencanaan untuk menghasilkan tampilan Instagram yang menggambarkan dirinya secara maksimal.Terakhir adalah kinerja.

Peneliti dapat berkesimpulan bahwa Olivia memiliki kinerja yang baik dalam menjaga Personal Branding.Hal ini karena Olivia sangat memerhatikan secara rinci profil Instagram untuk terlihat menarik dan dapat memperluas eksistensi profilnya.Adapun, Olivia belum dapat memenuhi kriteria keberbedaan dan goodwill dengan baik.Olivia melakukan upaya dalam menampilkan hal yang berbeda melalui format konten.

Hal ini dirasa kurang maksimal.Olivia dirasa harus melakukan keberbedaan yang bukan sekedar tampilan konten melainkan berdasarkan fashion style dan passion yang dimilikinya untuk dapat lebih unggul di pasar.Pada kriteria goodwill, Olivia dapat dikatakan memiliki nilai positif yang baik.Olivia berhasil menunjukkannya dengan kerjasama berbagai brand yang telah dilakoninya serta mendapatkan respon positif dari follower. Adapun, Olivia juga harus menjalin hubungan baik atau goodwill dengan brand lokal Indonesia yang kini semakin terkenal akan kualitasnya.
DAFTAR PUSTAKA

Aaker, David. (2014). Aaker On Branding. Jakarta: PT Gramedia Pustaka Utama. Budiargo, Dian. (2015), Berkomunikasi Ala Net Generation. Jakarta: Elex Media Komputindo.

Kotler, Philip. (2012). Manajemen Pemasaran. Jakarta: Erlangga

Nasrullah, Rulli. (2015), Media Sosial: Perspektif Komunikasi, Budaya, dan Sosioteknologi. Bandung: Simbiosa Rekatama Media.

Rampersad, H. K. (2008), Sukses Membangun Authentic Personal Branding. Jakarta: PPM.

Suryani, Tatik. (2008). Perilaku Konsumen. Yogyakarta: Graha Ilmu.

Vera, Nawiroh. (2016). Komunikasi Massa. Bogor: Ghalia Indonesia.

Zamroni, Mohammad. (2009), Filsafat Komunikasi: Pengantar Ontologis, Epistemologis, Aksiologis. Yogyakarta: Graha Ilmu.

\section{Sumber Internet :}

Dyah, Andina. 2014. Studi Elaboration Likelihood Model Pada Pengaruh Selebgram (Selebriti Endorser Instagram) Terhadap Minat Pembelian Dalam Media Sosial Instagram. (Sumber: https://www.academia.edu/8370228/J URNAL_ALL)

https://www.instagram.com/fashionartvibe/ https://www.instagram.com/olivialazuardy/ https://www.instagram.com/elxielvina/ https://www.instagram.com/michimomo/ https://www.instagram.com/soniaeryka/ http://www.harpersbazaar.co.id/articles/rea d/6/2017/4101/Apa-PerbedaanAntara-Fashion-Blogger-danInfluencer (Diakses pada Selasa, 25 Oktober 2017. 1:45) 